International Journal of Current Advanced Research

ISSN: O: 2319-6475, ISSN: P: 2319 - 6505, Impact Factor: SJIF: 5.995

Available Online at www.journalijcar.org

Volume 6; Issue 5; May 2017; Page No. 3613-3615

DOI: http://dx.doi.org/10.24327/ijcar.2017.3615.0331

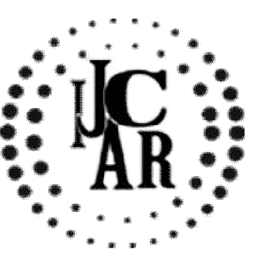

Research Article

\title{
RAPID AND EFFECTIVE METHOD FOR THE EXTRACTION OF THE GENOMIC DNA FROM SPERM
}

\section{Bhaumik D. Vaghela., Hiren S. Gajjar and Jayesh C. Jalondhara*}

Xcelris Labs, Ahmedabad, Gujarat, India

\section{A R T I C L E I N F O}

\section{Article History:}

Received $19^{\text {th }}$ February, 2017

Received in revised form $12^{\text {th }}$ March, 2017

Accepted $15^{\text {th }}$ April, 2017

Published online $28^{\text {th }}$ May, 2017

\begin{abstract}
A B S T R A C T
This investigation was aimed to isolate sperm genomic DNA in quick and efficient way. The sperm samples from the authors were taken and subjected to isolation of the genomic DNA. Then isolated DNA was further subjected to amplification. Sperm DNA was isolated in nearly half an hour. The isolated DNA from both the samples was intact. Amplification of the DNA was also successful. Sperm genomic DNA can be extracted using Xcelris sperm DNA kit and can be used for various downstream applications.
\end{abstract}

Key words:

Sperm DNA, Xcelgen kit, Amplification of sperm DNA.

Copyright $\bigcirc 2017$ Bhaumik D Vaghela et al. This is an open access article distributed under the Creative Commons Attribution License, which permits unrestricted use, distribution, and reproduction in any medium, provided the original work is properly cited.

\section{INTRODUCTION}

Various methods have been applied to extract DNA from different sources. Many techniques which are regularly used for the DNA isolation from the mammalian somatic cells are futile for the mammalian sperm $[1,2]$. Sperm DNA is extremely compacted because of sperm specific proteins called protamines. To prevent oxidation of genome within female reproductive tract and for the motility of sperm this compaction is necessary [3]. In sperm histones are replaced by the protamines which are low molecular proteins $[4,5]$. Protamines restrain sperm DNA extraction by the usual techniques applied for the somatic cells. There are many methods known for the sperm DNA extraction which includes [6] and [7] but they are laborious and time consuming. The methods have been progressed over the period of time howeverthere are drawbacks. Here, we have invented a new approach for the isolation of the DNA from sperm. It is very rapid, easy to perform and gives high quality of DNA.

\section{MATERIALS AND METHODS}

\section{Isolation of sperm genomic DNA}

We authors (Bhaumik and Jayesh) had provided the semen samples named sample A and sample B respectively. After 4

*Corresponding author: Jayesh C. Jalondhara

Xcelris Labs, Ahmedabad, Gujarat, India days of sexual abstinence, the samples were obtained through masturbation in $1.5 \mathrm{ml}$ nuclease free sterile microfuge tubes. Form that sperm samples were taken. The sperm DNA was extracted using Xcelris sperm gDNA mini kit in nearly half an hour.In brief the method includes,to proceed withsperm sample of $100-150 \mu \mathrm{l}$ in $1.5 \mathrm{ml}$ microfuge tube. Then add 0.5 $\mathrm{ml}$ Buffer 1 and vortex it for 10 seconds. Centrifuge at 10000 $\times \mathrm{g}$ for 5 minute. After that, carefully remove the supernatant, leaving the pellet. Repeat the above step. Re-suspend the pellet in $300 \mu$ l Buffer 2 with $3 \mu \mathrm{l}$ of $\beta$-Mercaptoethanol and mix it well. Afterwards, add $20 \mu \mathrm{l}$ of Proteinase $\mathrm{K}$ and incubate for 20 minutes at $55^{\circ} \mathrm{C}$. Mix lysate after interval of 5 minutes. Subsequently, add 1 volume of Buffer 3 and 0.5 volume of $96-100 \%$ ethanol. Mix well with inverting tubes for 8 times. Then shift the whole lysate to DNA column and centrifuge at $10000 \times \mathrm{g}$ for 1 minute.

Discard the flow through. After that, put the column into the same collection tube again. Add $500 \mu$ of Buffer 4 and centrifuge at $10000 \times \mathrm{g}$ for $1 \mathrm{~min}$. Discard the flow through liquid. Repeat the previous step. Centrifuge the empty DNA column with the lid open at $12000 \times \mathrm{g}$ for 3 minutes. Put the column into a new $1.5 \mathrm{ml}$ microfuge tube and add $30 \mu \mathrm{l}$ prewarmed $\left(60^{\circ} \mathrm{C}\right)$ Buffer 5 or $\mathrm{ddH}_{2} \mathrm{O}$ to the center of the column. There is an incubation period of 1 minute at room temperature. To elute DNA centrifuge at $12000 \times \mathrm{g}$ for 1 minute. After that reload the eluted DNA solution to the column. The quality of DNA was then evaluated by agarose gel electrophoresis, PCR validation. 


\section{Amplification and electrophoresis}

DNA yield was quantified by spectrophotometer. Genomic DNA (gDNA) of $200 \mathrm{ng} / \mu \mathrm{l}$ was resolved on a $0.8 \%$ agarose gel at $90 \mathrm{~V}$ for 45 minutes. It was stained with $0.5 \mu \mathrm{g} / \mathrm{mlethidium}$ bromide solution. After that it DNA was subjected to PCR amplificationwith cytochrome primers. CytochromeForward: 5'-CCATCCAACATCTCAGCATGATGAAA-3' and Cytochrome -Reverse: 5'-GCCCCTCAGAATGATATTTGTCCTCA3'. The primers were synthesized by Dr. Oligo 192 DNA/RNA synthesizer. In $50 \mu 1$ of reaction mixture with $10 \mathrm{ng}$ of DNA template, the PCR amplicons were made. PCR condition: I. Initial denaturation at $95^{\circ} \mathrm{C}$ for 3 minutes, denaturation at $95^{\circ} \mathrm{C}$ for 30 seconds, annealing at $55^{\circ} \mathrm{C}$ for 30 seconds, extension at $72^{\circ} \mathrm{C}$ for 30 secondsand last extension at $72^{\circ} \mathrm{C}$ for 10 minutes; 35 cycles.Amplified PCR products were separated through $1.5 \%$ agarose gel electrophoresis in TAE buffer on $100 \mathrm{~V}$ for 30 minutes. It was stained by ethidium bromide with the concentration of $0.5 \mu \mathrm{g} / \mathrm{ml}$.

\section{RESULTS AND DISCUSSION}

\section{RESULTS}

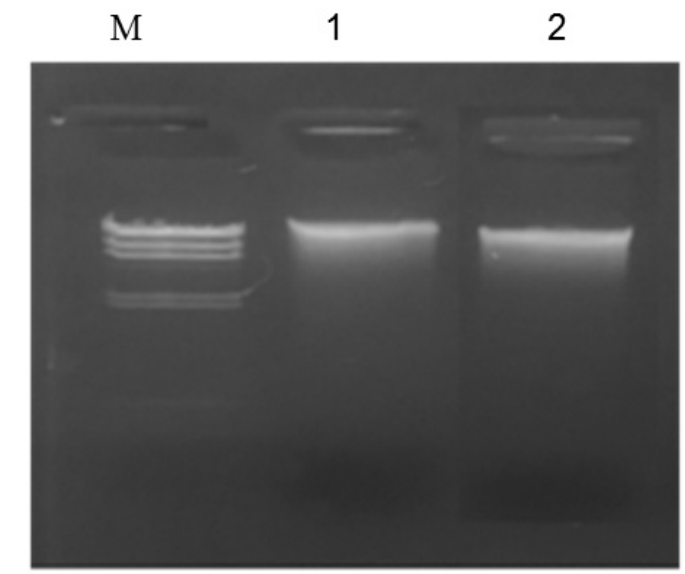

Figure 1 Agarose gel (0.8\%) electrophoresis (ethidium bromide stained) of isolated sperm DNA samples Lane M: HindIII DNA Marker, Lane 1: DNA isolated from Sample A and Lane 2: DNA isolated from Sample B.

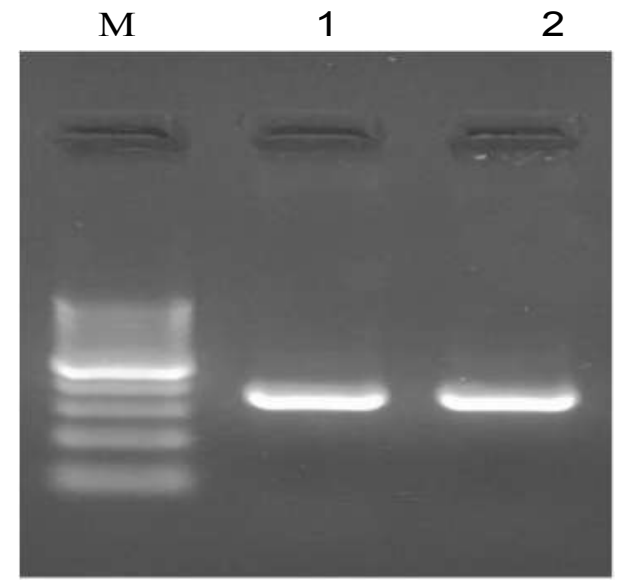

Figure 2: Agarose gel (0.8\%) electrophoresis (ethidium bromide stained) of PCR products, Lane M: $100 \mathrm{bp}$ DNA Marker, Lane 1: PCR product from Sample A and Lane 1: PCR product from Sample B.

The DNA was successfully isolated from both the samples by using above mentioned method and further evaluated for the amplification. From the figure 1, it is clearly visible that the genomic DNA extracted from sperm was intact. The yield was also high. Figure 2 represents the amplification of the DNA. The isolated DNA amplified successfully with primers. Amplicon sizes of the PCR products were around 359 base pairs.

Several studies proved that integrity of spermatozoal DNA is precondition for the successful paternal genetic information transformation to the offspring [8,9]. It is believed that nuclear compaction is vital for the defense of the sperm genome from external stresses like temperature elevation or oxidation [10]. It is the most distinctive feature of the sperm. Sperm DNA damage is plainly connected with male infertility although a little fraction of spermatozoa from the fertile men does possess noticeable amount of damaged DNA [11, 12]. Research on animal models by means of specific protamine deficiency indicates a relationship between sperm DNA damage, poor fertilizing capability during IVF and protamine deficiency [13]. An absolute protamine deficiency can be seen in infertile men [14]. The relationship between protamine deficiency and sperm DNA damage reveals that damagecan be because of deficiency in spermatogenesis. Sperm DNA damage possibly due to apoptosis [15]. There are various external factors like radiation, environmental toxins and cigarette smoking as well as internal factors like abnormal protamine ratio, reactive oxygen species, testicular hyperthermia and hormonal factors considered to affect the genome integrity of sperm [16]. DNA damage in sperm happens before it mixes with the seminal fluid. Mutations which arise during DNA replication can increase occurrence cancer or genetic defects in the progeny. Oxidative stress which leads to mutation during the early course of spermatogenesis can cause genetically flawed sperm population. Thus DNA repair mechanisms are vital in all the stages of the spermatogenesis previously to the nuclear condensation.

\section{CONCLUSION}

The genomic DNA from the sperm can be extracted from the method that we used in a speedy way. The extracted DNA can be used for different techniques.

\section{Acknowledgment}

The authors express their heartfelt gratitude to Xcelris labs limited for sponsoring the experiment and providing the facilities.

\section{References}

1. Shiurba $\mathrm{R}$ and Nandi $\mathrm{S}$. Isolation and characterization of germ line DNA from mouse sperm. ProcNatlAcadSci 1979; 76:3947-51.

2. Bahnak BR, WuQY, Coulombel L, Drouct L, Kerbiriou-NabiasD and MeyerD. A simple and efficient method for isolating high molecular weight DNA from mammalian sperm. Nucleic Acids Res 1988; 16:1208-9.

3. Oliva R. Protamines and male infertility. Hum Reprod Update 2006; 12:417-35.

4. Hammoud SS, Nix DA, Zhang H, Purwar J, Carrell DT, Cairns BR. Distinctive chromatin in human sperm packages genes for embryo development. Nature 2009; 460:473-8. 
5. Brykczynska U, Hisano M, Erkek S, Ramos L, Oakeley EJ, Roloff TC, et al. Repressive and active histone methylation mark distinct promoters in human and mouse spermatozoa. Nat StructMolBiol 2010; 17:679-87.

6. 6.Hossain AM, Rizk B, Behzadian A, Thorneycroft H. Modified guanidiniumthiocyanate method for human sperm DNA isolation. Mol Hum Reprod 1997; 3:9536.

7. Griffin J. Methods of sperm DNA extraction for genetic and epigenetic studies. Methods MolBiol 2013; 927:379-84.

8. Benchaib M, Lornage J, Mazoyer C, Lejeune H, Salle B, Francois Guerin J. Sperm deoxyribonucleic acid fragmentation as a prognostic indicator of assisted reproductive technology outcome. FertilSteril 2007; 87:93-100.

9. Collins JA, Barnhart KT, Schlegel PN. Do sperm DNA integrity tests predict pregnancy with in vitro fertilization?. FertilSteril 2008; 89:823-31.

10. Kosower NS, Katayose H and Yanagimachi R. Thioldisulfide status and acridine orange fluorescence of mammalian sperm nuclei. J Androl 1992; 13:342-8.
11. Kodama H, Yamaguchi R, Fukuda J, Kasai H, Tanaka $\mathrm{T}$. Increased oxidative deoxyribonucleic acid damage in the spermatozoa of infertile male patients. FertilSteril1997; 68:519-24.

12. Zini A, Kamal K, Phang D, Willis J, Jarvi K. Biologic variability of sperm DNA denaturation in infertile men. Urology 2001; 58:258-61.

13. Cho C, Jung-Ha H, Willis WD, Goulding EH, Stein P, $\mathrm{Xu} \mathrm{Z}$, et al. Protamine 2 deficiency leads to sperm DNA damage and embryo death in mice. BiolReprod 2003; 69:211-7.

14. Carrell DT, Liu L. Altered protamine 2 expression is uncommon in donors of known fertility but common among men with poor fertilizing capacity and may reflect other abnormalities of spermiogenesis. J Androl 2001; 22:604-10.

15. Sakkas D, Seli E, Manicardi GC, Nijs M, Ombelet W,Bizzaro D. The presence of abnormal spermatozoa in the ejaculate: did apoptosis fail? Hum Fertil 2004; 7:99-103.

16. Zini A, Libman J. Sperm DNA damage: importance in the era of assisted reproduction. CurrOpinUrol 2006; 16:428-34.

\section{How to cite this article:}

Bhaumik D. Vaghela et al (2017) ' Rapid And Effective Method For The Extraction Of The Genomic Dna From Sperm', International Journal of Current Advanced Research, 06(05), pp. 3613-3615.

DOI: http://dx.doi.org/10.24327/ijcar.2017.3615.0331 